\title{
Persistent Holocene Outflow from the Black Sea to the Eastern Mediterranean Contradicts Noah's Flood Hypothesis
}

\begin{abstract}
Ali E.Aksu, aaksu@sparky2.esd.mun.ca, and Richard N. Hiscott, Department of Earth Sciences, Memorial University of Newfoundland, St. John's, Newfoundland A1B 3X5, Canada
\end{abstract}

Peta J. Mudie and André Rochon, Geological Survey of Canada-Atlantic, P.O. Box 1006, Dartmouth, Nova Scotia B2Y 4A2, Canada

\begin{abstract}
Michael A. Kaminski, Research School of Geological and Geophysical Sciences, University College London, Gower Street, London WCIE 6BT, UK, and KLFR, 3 Boyne Avenue, Hendon NW4 2JL, UK
\end{abstract}

Teofilo Abrajano, Department of Earth and Environmental Sciences, Rensselaer Polytechnic Institute, Troy, New York 12180, USA

Doğan Yaşar, Institute of Marine Sciences and Technology (IMST), Dokuz Eylül University, Haydar Aliyev Caddesi No. 10, Inciraltı, Izmir, Turkey 35340

\section{ABSTRACT}

Controversy surrounds reconnection of the Black Sea and Mediterranean during Holocene sea-level rise. This reconnection and its causes have implications for European and Middle Eastern archaeology, paleoclimate, and marine sedimentation; e.g., genesis of organic-rich muds (sapropels). Bill Ryan, Walter Pitman, and co-workers propose reconnection via a catastrophic flood of Mediterranean water into the Black Sea at ca. $7.5 \mathrm{ka}$, with speculation that this was the historical basis for the biblical story of Noah's Flood. In contrast, this paper suggests a more complex and progressive reconnection over the past 12 k.y. Today, the Black Sea exports considerably more brackish water than the saline inflow it receives from the Mediterranean. There is a stratified, two-layer flow that has a strong effect on aquatic life and seabed sediments. The "Marmara Sea Gateway" (narrow straits of Dardanelles and Bosphorus, and deep intervening Marmara Sea) provides a set of natural flow valves (and sediment traps) that in principle should contain a record of the reconnection. Using $~ 7500$ line-km of seismic profiles, 65 soft-sediment cores, and 43 radiocarbon dates, we recognize a 10-11 k.y. history of low surfacewater salinities in the Marmara Sea and northern Aegean Sea. The low-density surface layer promoted uninterrupted water-column stratification and depleted oxygen concentrations at depth and is attributed to persistent Black Sea outflow across the Bosphorus Strait. Seismic data reveal a climbing delta on the middle shelf south of the Bosphorus exit, active only from ca. 10 to $9 \mathrm{ka}$ based on radiocarbon dating of its distal prodelta. The strength of the early outflow is confirmed by the progradation of this delta, and contemporaneous severe water-column stratification leading to deposition of sapropels in basinal areas. Ryan and Pitman's argument for a catastrophic Black Sea flood hinges on the rapid first appearance of euryhaline (Mediterranean) mollusks on Black Sea shelves at ca. $7.5 \mathrm{ka}$. In our view, this colonization was not a consequence of catastrophic flooding but rather the outcome of a slow establishment of two-way flow in the Bosphorus and a time lag during which the fresher waters of the deep Black Sea were replaced by more saline inflow, eventually allowing marine organisms to colonize the Black Sea shelves.

\section{INTRODUCTION}

The "Marmara Sea Gateway" connects the Black Sea and eastern Mediterranean (Fig. 1A and 1B) and consists of a linked set of narrow straits with shallow bedrock sills (Bosphorus Strait—sills $\sim 40 \mathrm{~m}$ deep; Dardanelles Strait—sills $\sim 70 \mathrm{~m}$ deep) and the inland Marmara Sea, locally deeper than 1200 $\mathrm{m}$. The gateway provides a natural laboratory in which to study evolution of the Quaternary climate of central and northern Europe. Today, the Black Sea is swollen by the discharge of major European rivers (Danube, Don, Dnieper, Dniester, Southern Bug) and exports $\sim 300 \mathrm{~km}^{3} / \mathrm{yr}$ of brackish water through the gateway. This is 50 times the cumulative annual discharge of the small rivers entering the Marmara Sea. Satellite altimetry shows that the surface of the Black Sea is $\sim 30 \mathrm{~cm}$ above the level of the Marmara Sea, which, in turn, is $\sim 5-27 \mathrm{~cm}$ above the level of the northern Aegean Sea (Polat and Tuğrul, 1996). These elevation differences drive the net outflow across the gateway. The present water exchange across the Bosphorus Strait is a twolayer flow. A cooler, lower salinity (17\%0-20\%) surface layer exits the Black Sea and warmer, higher salinity (38\%0-39\%0) Mediterranean water flows northward through the strait, at depth (Polat and Tuğrul, 1996). Except for the open Aegean Sea, the upper tens of meters of the water column in the gateway area are strikingly fresher than the deep water because of the Black Sea outflow (Fig. 1C). The low-density surface layer prevents ventilation of the deeper water column and promotes organic-matter preservation and benthic communities adapted to suboxic to dysoxic conditions (0.1-1.3 ml/1 $\mathrm{O}_{2}$ ). Organic-rich sapropels (muds with $>2 \%$ total organic carbon, or TOC) punctuate the Pliocene-Quaternary record of the 


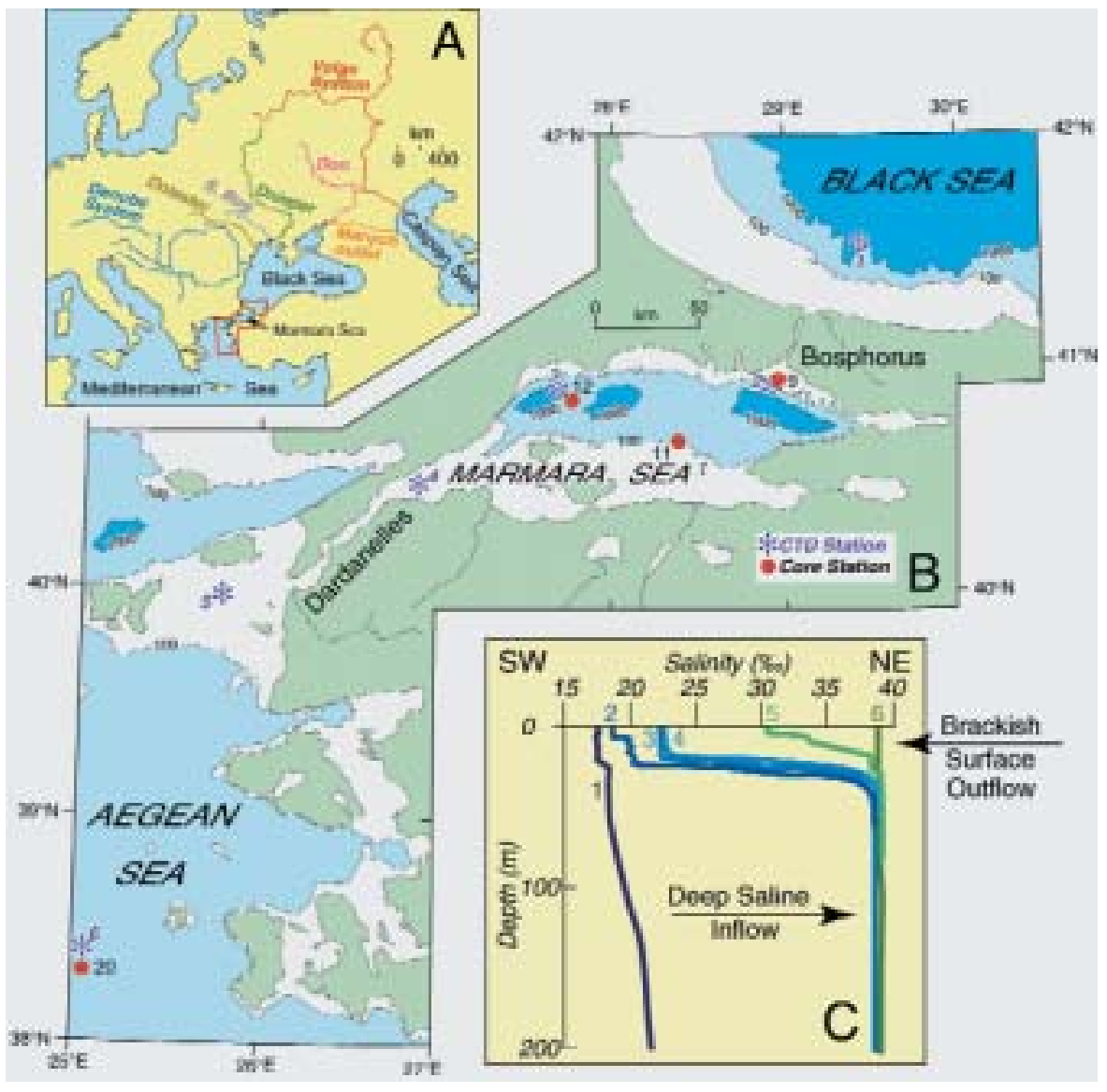

Figure 1. A: Location of the Marmara Sea, major European rivers entering the Black Sea, and part B. During deglaciation, the Volga system was connected to the Black Sea through the Manych outlet (Mamedov, 1997) and a link to the Don River. B: Simplified bathymetry in meters (Aksu et al., 1999b); location of cores, and conductivity-temperature-depth (CTD) stations 1-6, plotted in part C. Full core names: 20-AEG91-20; 11-MAR97-11; 9MAR98-09; 12-MAR98-12. C: Salinity versus water depth in the upper $200 \mathrm{~m}$ (stations 1, 3,6 ) or to the seabed (stations 2, 4, 5), showing sharp salinity-controlled pycnocline at $\sim 20-25 \mathrm{~m}$ except in the Black Sea (subtle pycnocline at $\sim 130 \mathrm{~m}$ ) and the southern Aegean Sea (no low-salinity layer). The low-salinity surface lid originates from Black Sea outflow and promotes permanent stratification, which in turn promotes sub-pycnocline oxygen depletion. Salinity (CTD) data from archives of Institute of Marine Sciences and Technology.

eastern Mediterranean area, in part as a result of particularly strong periods of water-column stratification associated with Black Sea outflow (Aksu et al., 1995).

During Quaternary glaciations of the past $150 \mathrm{k} . \mathrm{y}$. (oxygen isotopic stages 6, $4,2)$, the straits were subaerially exposed (Yaltırak et al., 2002) and the present Marmara and Black seas were lakes. The reconnection of the Black Sea to the Mediterranean following the last glaciation has become an issue of intense controversy. Ryan et al. (1997) proposed the "Flood Hypothesis": a catastrophic refilling of the Black Sea basin at ca. $7.5 \mathrm{ka}$ that took place in $<2$ yr. Before this event, the water level stood $\sim 150$ m below modern sea level
(Fig. 2A). They link this deluge with the biblical account of Noah's Flood and explain a low Black Sea (Lake) well into the Holocene by advocating a dry central European climate. Because the Mediterranean and Marmara water levels had already risen to $-15 \mathrm{~m}$ by rock sills in the Bosphorus Strait, Ryan et al. (1997) require a hypothetical sediment dam to hold back the global ocean. At the time of reconnection, they propose that "The soil and debris that had once dammed the [Bosphorus Strait] were quickly swept away.... Ten cubic miles of [Mediterranean] water poured through each day, two hundred times what flows over Niagara Falls," ca. $7.5 \mathrm{ka}$, well above the present bed-
(Ryan and Pitman, 1999, p. 234). Radiocarbon dates of ca. $7.5 \mathrm{ka}$ for the first euryhaline mollusks (salinity tolerance $\sim 20 \%-40 \%$; Knox, 1986) to populate the drowned shelves of the northern Black Sea are used to date the flood. Many readers will be familiar with the Flood Hypothesis from articles in National Geographic (May 2001), Scientific American (February 1999), New Scientist (October 4, 1997), Earth (August 1998), and other media (e.g., BBC documentary, "Horizon,"

December 16, 1996).

The controversy triggered by the widespread publication of the Flood Hypothesis has catalyzed new interest in the paleoceanography of this region and has forced a thorough reexamination of diverse data sets. We began to study the gateway area in 1995 and have acquired $~ 7500$ line-km of airgun, sparker, and Huntec boomer profiles (vertical resolution $\sim 10-20 \mathrm{~cm}$ ), 65 short cores, and 43 radiocarbon dates from cores (Aksu et al., 1999b, 2002a, 2002b; Hiscott et al., 2002; Mudie et al., 2001, 2002a, 2002b; Kaminski et al., 2002; Abrajano et al., 2002). The essential observations that can be used to resolve the controversy surrounding reconnection are summarized for the first time in this paper and point to persistent southward export of lowsalinity water from the Black Sea since at least $10 \mathrm{ka}$ (Fig. 2A). Seismic, geochemical, sediment, microfossil, and palynological data provide no support whatsoever for a catastrophic northward flow of saline Mediterranean water.

Instead, we explain the reconnection by an "Outflow Hypothesis" (Fig. 2B) in which the Black Sea rose to the Bosphorus sill depth by ca.11-10 ka, when the Marmara Sea was $20 \mathrm{~m}$ lower. The burgeoning Black Sea fed a brackishwater torrent that deposited a delta at the southern end of the Bosphorus Strait and that strongly influenced microfossil communities and sediment characteristics across the gateway. The Black Sea was refilled by the Danube, Dniester, Southern Bug, Dnieper, and Don Rivers, augmented at times by the Volga discharge through the Manych outlet (Mamedov, 1997) and connection to the Don valley (Fig. 1A). The combined drainage area of these six rivers equals that of the Mississippi-Missouri 


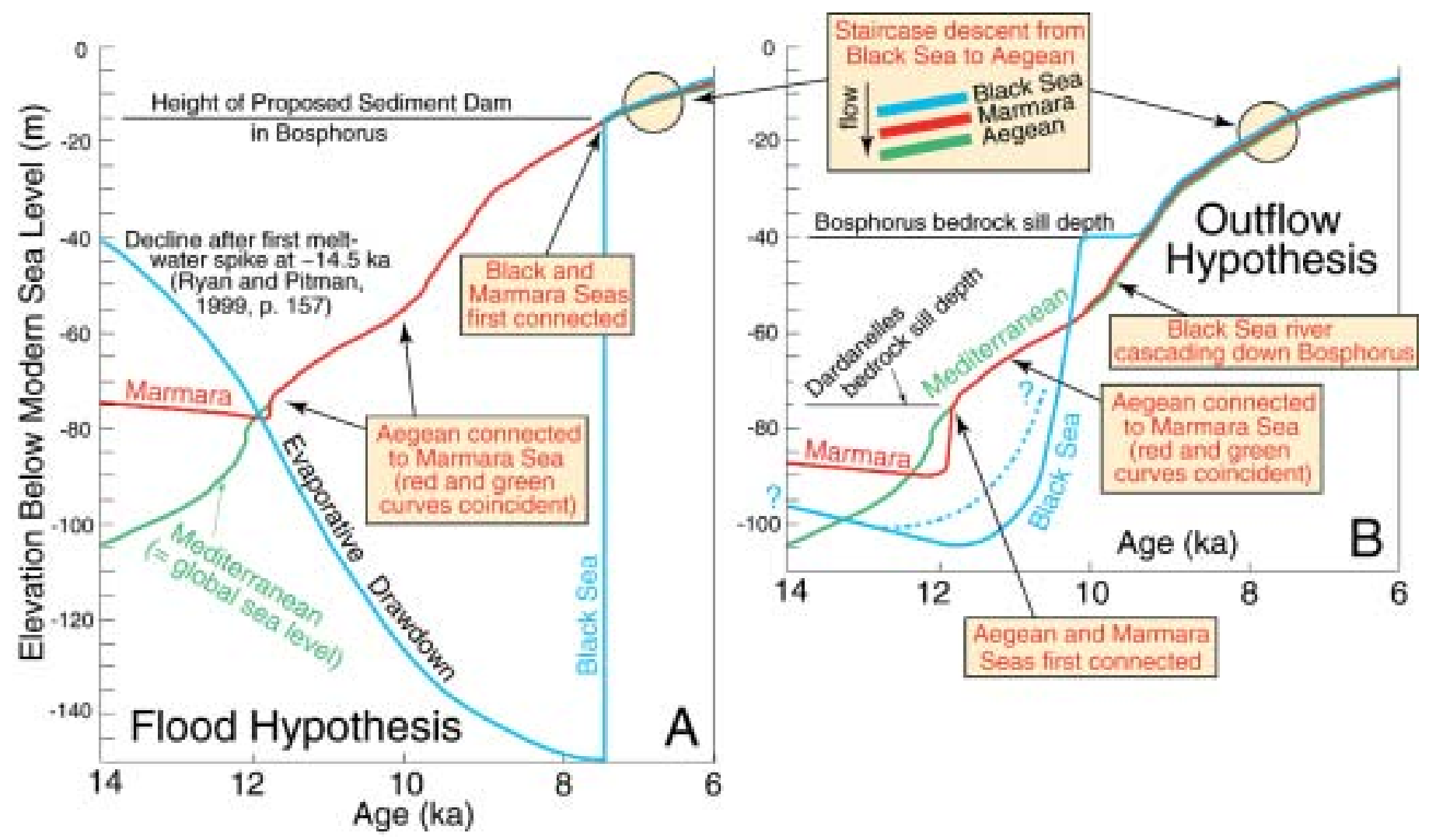

Figure 2. Schematic water-level histories of the Black Sea, Marmara Sea, and Mediterranean (Aegean) Sea according to the Flood Hypothesis (A; Ryan and Pitman, 1999) and the Outflow Hypothesis (B; Aksu et al., 1999b; Aksu et al., 2002b; Hiscott et al., 2002). In both plots, the Mediterranean curve is the Barbados (global) curve of Fairbanks (1989). When Mediterranean and Marmara curves are superimposed (from ca. 12 to $10 \mathrm{ka}$ ), the Marmara Sea was an embayment of the Mediterranean. According to the Flood Hypothesis, the Marmara and Mediterranean catastrophically flooded into the depressed Black Sea basin when a hypothetical sediment dam in the Bosphorus channel was scoured away;

subsequently, the Black Sea began to flow outward across the gateway. The Flood Hypothesis predicts thorough mixing of the Marmara Sea water column until ca. 7.5 ka with a final turbulent stirring and flushing in of Mediterranean fauna and flora. According to the Outflow Hypothesis, the Black Sea reached a -40 m bedrock sill depth in the Bosphorus Strait first, initiating a cascade downslope into the rising Marmara Sea and building the delta of Figure 4. This hypothesis does not involve a catastrophic flood. The Outflow Hypothesis predicts stratification and low oxygen conditions in the Marmara Sea since ca. $10 \mathrm{ka}$, similar to today (Figure 1C). system. Although the Flood Hypothesis requires that eastern Europe was dry prior to ca. $7.5 \mathrm{ka}$, a large body of palynological data from lakes in the region and marine studies document increased precipitation and a wetter climate starting earlier, at ca. $12 \mathrm{ka}$ (Harrison et al., 1996; Mudie et al., 2002b).

\section{CORE DATA}

Four 125-235 cm-long cores-three in the Marmara Sea and one in the Aegean-clarify the history of the gateway area since ca. $15 \mathrm{ka}$ (Figs. 1B and 3). Black Sea cores are discussed elsewhere (Aksu et al., 2002b) because they do not constrain the reconnection as well as gateway cores. Sediments are mainly burrowed muds with scattered shells, except for sand below $95 \mathrm{~cm}$ in
Core 9 and laminated muds in sapropels. Downcore plots were recast into the time dimension using 13 radiocarbon dates and, for Aegean Core 20, additional age picks for Santorini ash Z-2 and the oxygen isotopic stage $2 / 1$ transition.

Benthic foraminifera allow estimation of bottom water oxygenation, using the benthic foraminiferal oxygen index (BFOI) of Kaiho (1994). Low values indicate dysoxic conditions at the seabed below a stratified water column (Kaminski et al., 2002). In the central Marmara Sea and northern Aegean Sea (Cores 12 and 20), values are lowest and hence greatest stratification occurred during deposition of organicrich sapropels from ca. 10 to $6.5 \mathrm{ka}$. In contrast, off active southern-shelf deltas in the Marmara Sea and at the southern exit of the Bosphorus Strait (Cores 11 and 9; Figs. 1B and 4A), stratification has persisted since postglacial inundation (ca. $12 \mathrm{ka}$ at core site 11 and ca. $9 \mathrm{ka}$ at core site 9).

We measured the carbon isotopic composition, $\delta^{13} \mathrm{C}$, of a number of fatty acids like the dominant $n$-hexadecanoic acid $\left(\mathrm{C}_{16}\right)$ and $\mathrm{n}$-octadecanoic acid $\left(\mathrm{C}_{18}\right)$. In Cores 20 and 12, the highest TOC occurs in sediments deposited from $10-6.5 \mathrm{ka}$, at or just above an interval with the most negative $\delta^{13} \mathrm{C}_{16}$ and $\delta^{13} \mathrm{C}_{18}$ (Fig. 3; Aksu et al., 1999a, Abrajano et al., 2002). $\delta^{13} \mathrm{C}$ in the carbon fixed by photosynthesizers reflects the $\delta^{13} \mathrm{C}$ in the dissolved inorganic carbon (DIC) used by these organisms. An effective way to deplete 

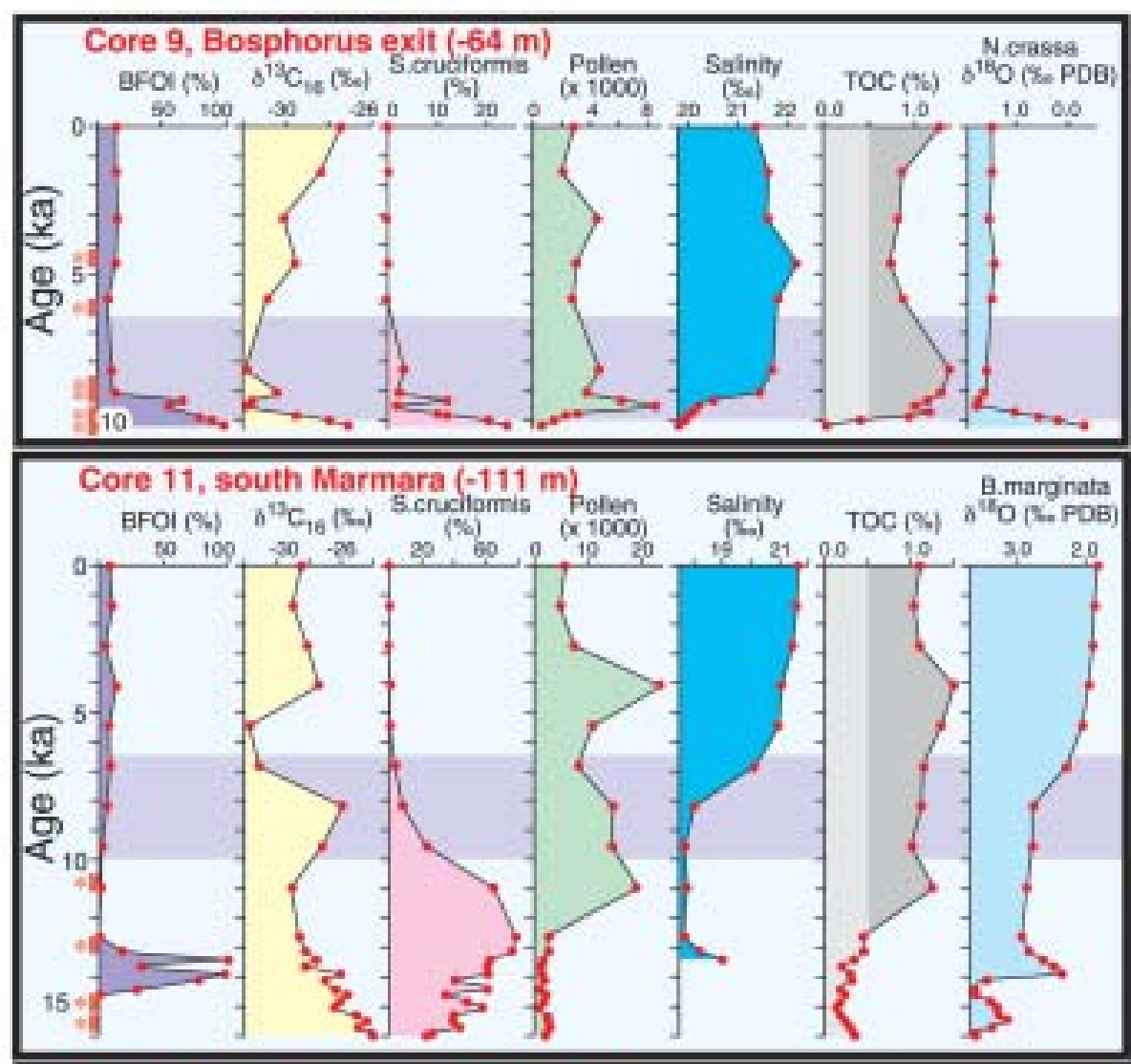

Core 12, central Marmara (-549 m)
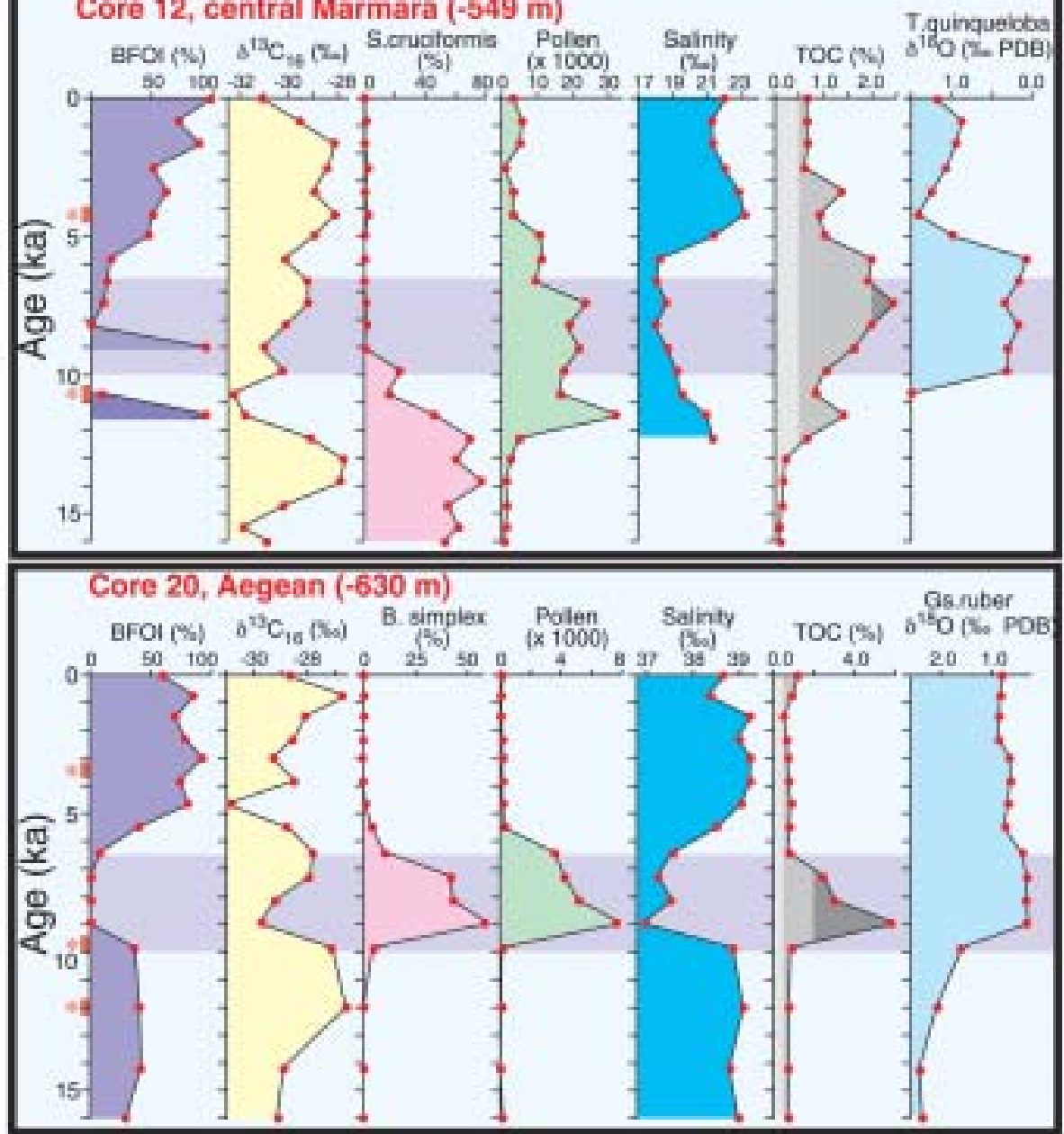

${ }^{13} \mathrm{C}$ in the water column DIC and lower $\delta^{13} \mathrm{C}$ is to increase the contribution of respired carbon relative to atmospheric abundances. This is exactly what would occur in an unventilated (stratified) water column, whereas enhanced net primary production would create the opposite fatty-acid $\delta^{13} \mathrm{C}$ trend. Black Sea outflow was the probable cause of the stratification.

Dinoflagellate cysts Brigantedinium simplex (Fig. 3A) and Spiniferites cruciformis (Fig. 3B, 3C, and 3D) are sensitive indicators of low-salinity marine, and fresh and/or brackish water conditions, respectively, and can be used to trace water masses. Mildly brackish water conditions prevailed in the Marmara Sea before its reconnection with the Aegean at ca. $12 \mathrm{ka}$ (Cores 11 and 12), continued until ca. $9 \mathrm{ka}$ off river deltas of the southern Marmara shelf (Core 11), and accompanied the development of sapropel in the Aegean Sea from ca. 10 to $6.5 \mathrm{ka}$ (Core 20). The only realistic source of significant brackish water in the northern Aegean Sea is outflow from the Black Sea, because small rivers in the region have insufficient catchments and discharges. The ouflow is confirmed in Core 12 by a broad peak in Peridinium ponticum (endemic to the Black Sea) from ca. 11 to $6 \mathrm{ka}$ (Mudie et al., 2002b). Thus Black Sea overflow began prior to the hypothesized flood.

Pollen abundance indicates increased terrigenous supply from rivers beginning at ca. 11-10 ka and declining in the

Figure 3. Downcore plots of key proxy variables, explained in text. Core locations in Figure 1B. The water depth at each site is indicated (e.g., $-630 \mathrm{~m}$ ). Samples have been transposed into a time domain using radiocarbon dates tabulated in Aksu et al. (2002a), and the oxygen-isotope and ash record in Core 20. Control points are marked by red * symbols along the age scale. Where red dots (sample positions) cluster, the accumulation rate was highest (e.g., deltaic strata at the base of Cores 11 and 9). Where red dots are missing for some variables, the species required for determinations were absent (e.g., Turborotalita quinqueloba before ca. 10 ka for Core 12). The mauve-colored band from ca. 10-6.5 ka coincides with sapropel deposition and significant changes in several proxy variables. 


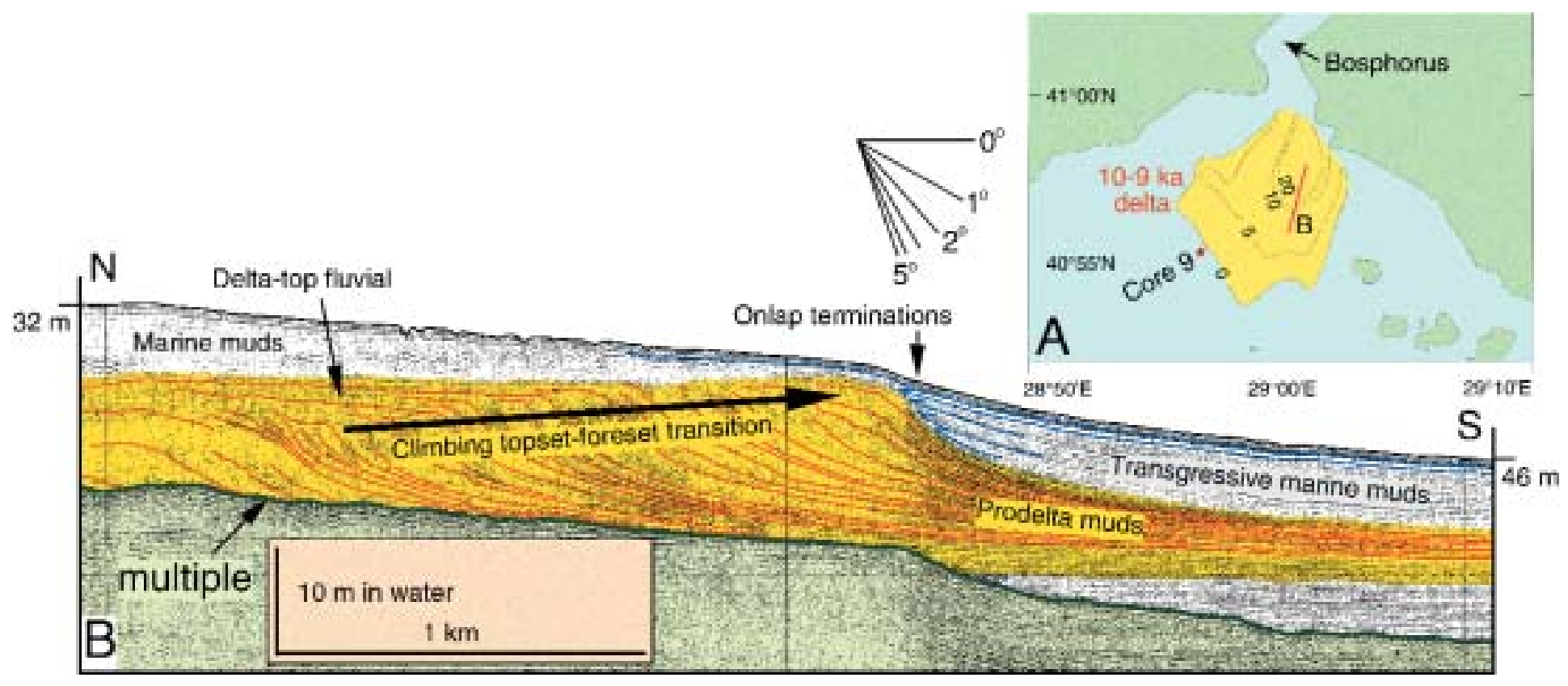

Figure 4. Outflow delta lobe in plan (A: sediment thicknesses in milliseconds of two-way traveltime where $10 \mathrm{~ms} \approx 7.5 \mathrm{~m}$ ) and cross section (B: Huntec deep-towed boomer profile). The topset-foreset transition (offlap break) climbs consistently from north to south, indicating progradation during a relative sea-level rise. Foresets dip $\sim 2^{\circ}$. Core 9 (Fig. 3) was raised from the distal prodelta fringe. central Marmara and Aegean seas by ca. $6 \mathrm{ka}$ (Cores 12 and 20). The persistent moderate pollen abundances at the southern exit from the Bosphorus Strait (Core 9) since ca. $9.5 \mathrm{ka}$ are ascribed to pollen input into the Black Sea from major European rivers. Pollen profiles of southern Black Sea cores show no evidence of human settlement (deforestation or agriculture) before ca. $4 \mathrm{ka}$ (Mudie et al., 2002b). This conflicts with the Ryan and Pitman (1999) hypothesis of widespread agricultural activity on Black Sea shelves before their proposed catastrophic flood.

Paleo-sea-surface salinity (SSS) was calculated as explained in Aksu et al. (1995) using a Mediterranean-based transfer function to determine seasurface temperatures, the paleotemperature equation of Shackleton (1974) to determine $\delta^{18} \mathrm{O}$ of the ancient surface waters, and empirical data to relate these latter values to salinity. In the Aegean and central Marmara seas, SSS dropped dramatically during sapropel deposition (Cores 20 and 12). SSS at the southern exit from the Bosphorus Strait was depressed from ca. 10 to $9 \mathrm{ka}$, consistent with high abundances of the fresh and/or brackish-water indicator, dinocyst S. cruciformis.
Elevated TOC in Aegean Sea sediments coincides with lowered SSS, increased terrigenous supply of pollen, and increased stratification of the water column (low BFOI). In the Marmara Sea, TOC has been persistently high since ca. 11-10 ka, with a moderate decrease since ca. 5-3 ka away from the Bosphorus exit (Cores 12 and 11). Pollen abundance mimics these trends, confirming the terrestrial origin of the organic matter (Mudie et al., 2002b; Abrajano et al., 2002). The core data indicate development of a brackishwater surface layer in the Marmara Sea by ca. 11-10 ka, with strongest watercolumn stratification from ca. 10 to $6.5 \mathrm{ka}$ when widespread sapropel developed in the gateway area. Today, the brackish-water surface layer originates entirely from Black Sea outflow. There is no interruption in the degree of stratification at ca. $7.5 \mathrm{ka}$, as would surely have accompanied a catastrophic flood. Similarly, the failure of open-marine foraminifera to colonize the Marmara Sea at ca. $7.5 \mathrm{ka}$ is inconsistent with a major flood (Aksu et al., 2002b; Kaminski et al., 2002).

\section{OUTFLOW DELTA AT THE SOUTHERN BOSPHORUS EXIT}

Perhaps the best physical evidence for early and strong Black Sea outflow is a 10-9 ka delta lobe at the southern exit of the Bosphorus Strait (Fig. 4). Its age is constrained by radiocarbon dates in the distal prodelta (Core 9, Fig. 4A). The only source for the deltaic sediment is the strait itself. There is no shelf-edge delta here, only a mid-shelf delta with a topset-to-foreset transition that climbs in the seaward direction, indicating delta progradation into a rising water body. We compared the elevation of the topset-to-foreset transition to the Holocene global sealevel curve (Fig. 2). Global sea level is only compatible with a delta at this elevation during a narrow window of time, from ca. 10 to $9 \mathrm{ka}$. Before ca. 10 $\mathrm{ka}$, this part of the shelf was subaerially exposed; after ca. $9 \mathrm{ka}$, the delta would have been drowned by rising sea level. Abandonment of the delta lobe at ca. 9 ka coincided with an increase in SSS at core site 9 (Fig. 3), presumably because of diminished brackish-water outflow through the strait and northward penetration of a saline wedge under the surface-water layer (Hiscott et al., 2002). Subsequently, a drape of transgressive-to-highstand mud accumulated here and throughout the Marmara Sea (Hiscott and Aksu, 2002). The resultant water-column 
stratification (estuarine circulation) promoted dysoxic bottom conditions that have persisted to the present

(Fig. 3, BFOI).

\section{THE RECONNECTION PROCESS, WITH IMPLICATIONS FOR PIONEERING MOLLUSKS}

When the Aegean Sea first flooded across the Dardanelles Strait at ca. 12 $\mathrm{ka}$, the surface of the Marmara Sea had an elevation of $\sim-90 \mathrm{~m}$. Coastal areas were quickly flooded to an elevation of $-75 \mathrm{~m}$, drowning a lowstand unconformity and barrier islands (Fig. 2B; Hiscott and Aksu, 2002). The effects of the Mediterranean incursion are best seen in Core 12 (Fig. 3; SSS of 20\% $-21 \%$, falling S. cruciformis, sudden arrival of planktonic foraminifera Turborotalita quinqueloba). Away from deltas of the southern shelf and Bosphorus exit, a widespread mud drape quickly began to accumulate even in the narrow Dardanelles entrance and continues to accumulate today. There is no evidence for erosion of this drape by strong currents at ca. $7.5 \mathrm{ka}$. The Marmara Sea then continued to rise with the global ocean. By ca. 11-10 ka, the Black Sea had risen to the Bosphorus bedrock sill depth of $-40 \mathrm{~m}$ and began to spill into the Marmara Sea, producing a climbing delta at the southern end of the strait and initiating a period of uninterrupted outflow and water-column stratification. For the first $\sim 1000 \mathrm{yr}$, the Black Sea was likely significantly higher than the Marmara Sea (Fig. 2B), so that the Bosphorus channel may have been occupied by a south-flowing river supplied entirely by Black Sea outflow. Later, by ca. $9 \mathrm{ka}$, the Marmara Sea rose to the level of the sills in the Bosphorus, and perhaps 500-1000 yr later a saline wedge had penetrated well into the strait, leading ultimately to the initiation of a two-layer flow by perhaps ca. $8 \mathrm{ka}$ (Lane-Serff et al., 1997; Kaminski et al., 2002).

On the southwestern Black Sea shelf, a set of back-stepping barrier islands convince us that the transgression was not geologically instantaneous (Aksu et al., 2002a). We infer, based on extrapolated core dates, that lowstand shelf-edge deltas in the Black Sea were inundated by ca. 12-11 ka as a con- sequence of increased precipitation over Europe (Harrison et al., 1996). Black Sea outflow was initially quite strong, filling the entire cross section of the Bosphorus. Only when the outflow became weaker and the global ocean matched the Black Sea height did the first saline Mediterranean deep water begin to cross the Bosphorus Strait. We estimate that this first true reconnection of the Black Sea and the Mediterranean Sea took place at ca. $8 \mathrm{ka}$, delayed because of the time lag involved with developing two-layer flow (Lane-Serff et al., 1997). Once initiated, protracted filling of the deeper central regions of the Black Sea with more dense saline water would have been a prerequisite to the successful colonization of shallow shelf areas by euryhaline mollusks. The radiocarbon dates of ca. 7.5 ka reported by Ryan et al. (1997) record, in our view, the rising of the Black Sea pycnocline (density interface above the saline deep water) to shelf depths, allowing open-marine fauna to live in these areas. Previously, the surface 100-200 m was too fresh and the salinity was likely too rapidly changing to permit even opportunist species to colonize the seabed.

\section{CONCLUSIONS}

We are convinced that the Outflow Hypothesis provides the best explanation for seismic, sediment, and fossil data in the Marmara Sea Gateway. Many of our observations are entirely incompatible with a late catastrophic flooding of the Black Sea, a circumstance that provides sufficient grounds to discard this hypothesis, following accepted scientific methodology. Nevertheless, there are new intriguing issues that demonstrate a need to more systematically evaluate the late Quaternary history of the gateway. The pre-Holocene sea-level history in the Black Sea is still poorly constrained. Sea-level rise may have started as early as ca. $17 \mathrm{ka}$ as postulated by Pirazzoli (1996), or may have been delayed until ca. $11 \mathrm{ka}$ as inferred by Aksu et al. (2002a). The pace of saltwater flow into the Black Sea basin, and the manner in which invertebrate organisms adapt and migrate into new and changing environments are central to a full understanding of the significance of the
$7.5 \mathrm{ka}$ date for the arrival of pioneering euryhaline mollusks. More generally, many lessons can be learned in the gateway area regarding the oceanography of marginal seas, lags in the establishment of water-mass and biotic linkages across narrow straits, and controls on the accumulation of organic-rich muds. Many of these issues can only be addressed in the Marmara Sea Gateway-nowhere else on Earth is there a comparable naturally regulated link between a large inland sea and the global ocean.

\section{ACKNOWLEDGMENTS}

We thank Erol Izdar and Orhan Uslu (former directors, Institute of Marine Sciences and Technology) and the officers and crew of the R/V Koca Piri Reis. Funding and in-kind support were provided by the Natural Sciences and Engineering Research Council of Canada, the Piri Reis Foundation, and the Geological Survey of Canada. We thank Marc De Batist, David Piper, and Karl Karlstrom for their reviews of the manuscript.

\section{REFERENCES CITED}

Abrajano, T., Aksu, A.E., Hiscott, R.N., and Mudie, P.J., 2002, Aspects of carbon isotope biogeochemistry of late Quaternary sediments from the Marmara Sea and Black Sea: Marine Geology (in press)

Aksu, A.E., Yaşar, D., and Mudie, P.J., 1995, Paleoclimatic and paleoceanographic circumstances leading to the development of sapropel layer S1 in the Aegean Sea basins: Palaeogeography Palaeoclimatology Palaeoecology, v. 116, p. 71-101.

Aksu, A.E., Abrajano, T., Mudie, P.J., and Yaşar, D. 1999a, Organic geochemical and palynological evidence for the Aegean Sea sapropel S1: Marine Geology, v. 153, p. 303-318.

Aksu, A.E., Hiscott, R.N., and Yaşar, D., 1999b, Oscillating Quaternary water levels of the Marmara Sea and vigorous outflow into the Aegean Sea from the Marmara Sea-Black Sea drainage corridor: Marine Geology, v. 153, p. 275-302.

Aksu, A.E., Hiscott, R.N., Kaminski, M.A., Mudie, P.J. Gillespie, H. Abrajano, T., and Yasar, D, 2002a, Last glacial-Holocene paleoceanography of the Black Sea and Marmara Sea: Stable isotopic, foraminiferal, and coccolith evidence: Marine Geology (in press).

Aksu, A.E., Hiscott, R.N., Yaşar, D., Işler, F.I., and Marsh, S., 2002b, Seismic stratigraphy of late Quaternary deposits from the southwestern Black Sea shelf: Evidence for noncatastrophic variations in sea level during the last 10,000 years: Marine Geology (in press).

Fairbanks, R.G., 1989, A 17,000 year glacio-eustatic sea-level record: Influence of glacial melting rates on the Younger Dryas event and deep-ocean circulation: Nature, v. 342, p. 637-642.

Harrison, S.P., Yu, G., and Tarasov, P., 1996, Late Quaternary lake-level record from northern Eurasia: Quaternary Research, v. 45, p. 138-159.

Hiscott, R.N., and Aksu, A.E., 2002, Late Quaternary history of the Marmara Sea and Black Sea from highresolution seismic and gravity core studies: Marine Geology (in press). 
Hiscott, R.N., Aksu, A.E., Yaşar, D., Kaminski, M.A., Mudie, P.J., Kostylev, V., MacDonald, J., Işler, F.I., and Lord, A.R., 2002, Deltas south of the Bosphorus Strait record persistent Black Sea outflow to the Marmara Sea since $10 \mathrm{ka}$ : Marine Geology (in press).

Kaiho, K., 1994, Benthic foraminiferal dissolved-oxygen index and dissolved-oxygen levels in the modern ocean: Geology, v. 22, p. 719-722.

Kaminski, M.A., Aksu, A.E., Hiscott, R.N., Box, M., Al-Salameen, M., and Filipescu, S., 2002, Late glacial to Holocene benthic foraminifera in the Marmara Sea: Marine Geology (in press).

Knox, G.A., 1986, Estuarine Ecosystems: A systems approach, volume 1: Boca Raton, Florida, USA, CRC Press, $289 \mathrm{p}$.

Lane-Serff, G., Rohling, E.J., Bryden, H.L., and Charnock, H., 1997, Postglacial connection of the Black Sea to the Mediterranean and its relation to the timing of sapropel formation: Paleoceanography, v. 12, p. 169-174.

Mamedov, A.V., 1997, The late Pleistocene-Holocene history of the Caspian Sea: Quaternary International, v. $41-42$, p. $161-166$

Mudie, P.J., Aksu, A.E., and Yaşar, D., 2001, Late Quaternary dinocysts from the Black, Marmara, and Aegean Seas: Variations in assemblages, morphology, and paleosalinity: Marine Micropaleontology, v. 43, p. $155-178$.

Mudie, P.J., Rochon, A., and Aksu, A.E., 2002a, Pollen stratigraphy of late Quaternary cores from Marmara Sea: Land-sea correlation and paleoclimatic history: Marine Geology (in press).

Mudie, P.J., Rochon, A., Aksu, A.E., and Gillespie, H 2002b, Dinoflagellate cysts and freshwater algae and fungal spores as salinity indicators in late Quaternary cores from Marmara and Black Seas: Marine Geology (in press).

Pirazzoli, P.A., 1996, Sea-level changes: The last 20000 years: New York, John Wiley \& Sons, 211 p

Polat, C.., and Tuğrul, S., 1996, Chemical exchange between the Mediterranean and Black Sea via the Turkish Straits, in Briand, F., ed., Dynamics of Mediterranean straits and channels: Bulletin de l'Institut Océanographique, Monaco, Special No. 17, CIESME Science Series No. 2 , p. 167-186.

Ryan, W.B.F., and Pitman, III, W.C., 1999, Noah's Flood: The new scientific discoveries about the event that changed history: New York, Simon \& Schuster, 319 p. Ryan, W.B.F., Pitman, III, W.C., Major, C.O., Shimkus, K., Maskalenko, V., Jones, G.A., Dimitrov, P., Görür, N., Sakınç, M., and Yüce, H., 1997, An abrupt drowning of the Black Sea shelf: Marine Geology, v. 138, p. 119-126.

Shackleton, N.J., 1974, Attainment of isotopic equilibrium between ocean water and benthonic foraminifera genus Uvigerina: Isotopic changes in the ocean during the last glacial: Centre National de Recherche Scientifique et Colloques Internationales, v. 219, p. 203-209.

Yaltırak, C., Sakınç, M., Aksu, A.E., Hiscott, R.N., Galleb, B., and Ülgen, U.B., 2002, Global sea-level variations and raised coastal deposits along the southwestern Marmara Sea during the last 224,000 years: Marine Geology (in press).

Manuscript received January 14, 2002; accepted March 8, 2002.

\section{DIALOGUE}

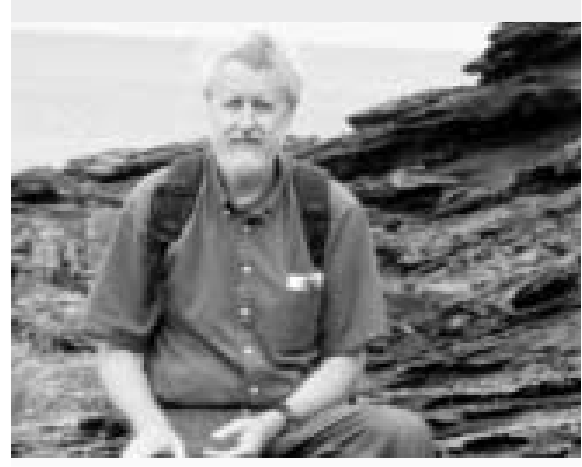

James "Bud" Alcock

\section{Enthusiasm for Earth System Science Continues at GSA}

\begin{abstract}
James "Bud" Alcock, Pennsylvania State University, Abington College
\end{abstract}

Many of my younger colleagues will not be familiar with the Whole Earth Catalogue, a wonderful '60s-'70s compilation of ideas and tools for alternative lifestyles. It was an attempt to bring many disparate areas of interest, knowledge, and technology together in a single integrated resource. The growing field of earth systems science reminds me of the catalog. In a world where science so often tends toward evergreater fragmentation and specialization, earth systems science recognizes the complex connections that act within different realms of the geoscience and across disciplines. Much as the shift in biology to an ecology-based science in the late 1960 s revolutionized our understanding of evolution and biological function, viewing Earth as a single complex system has the potential to allow us to develop a truly global view of our planet and its history.

My first exposure to earth systems science occurred shortly after I joined the Department of Environmental Sciences at Penn State Abington. Lee Kump, Jim Kasting, Rob Crane, Kate Freeman, and Eric Barron at University Park were developing an introductory course that used systems and graphical analysis to study Earth's physical environment. Asked to teach the course at the Abington Campus, I simply fell in love with its ideas, especially the intellectual power that can be obtained from systems analysis supported by simple models. The key is a recognition of the importance of feedback in controlling change within natural systems.

For example, I model the Amazon rainforest ecosystem and the effect of deforestation on system stability for my students. In the forest, there is positive feedback between levels of precipitation and the amount of area covered by healthy forest. Significant decreases in precipitation would be expected to cause losses within the forest. Loss of trees will reduce evapotranspiration in the area and so reduce overall humidity and precipitation. What I find interesting about the system is that this feedback has the potential to stabilize a healthy rainforest and to create a point of no return within the system after significant deforestation. If the point of no return were reached, runaway behavior would lead to collapse of the ecosystem. A simple analysis recognizing interconnections between forest, climate, and human behavior leads to a depressing but important prediction.

It is the ability of systems analysis to cut through the complexity of an earth system to identify its most important functions and components that makes it such a powerful tool. Obviously, a simple analysis, such as the one I describe above, may be wrong. However, even if proven incorrect, I would argue the analysis is important because it identifies questions that need to be answered and so is a valuable tool in directing research.

This past summer, GSA and the Geological Society of London sponsored a joint meeting, Earth Systems Processes. The meeting was full of ideas and intellectual energy based on a systems approach to the earth sciences. As Sharon Mosher said in an earlier "Dialogue" reporting on the event, "... it has been years since I have attended a meeting that had such scientific enthusiasm." Topics ranged from snowball Earth (both the why it could and why it couldn't happen), to changes in atmospheric carbon over time, to the effects of temperature of Venutian plate tectonics, among many others. This fall in Denver, Lee Kump and I hope to recapture a little of that meeting's magic in a technical session that explores the role of feedback in controlling earth systems. We encourage you to use this opportunity to learn more about earth systems science if you are not familiar with it or to share your ideas and research on earth systems if you are. 


\section{ERRATUM}

In our paper challenging the Noah's Flood Hypothesis for catastrophic flooding of the Black Sea (Aksu et al., 2002), proper acknowledgement was mistakenly not given to similar criticisms of this hypothesis in the literature. In particular, Çağatay et al. (2000), Görür et al. (2001), and Algan et al. (2001) have all criticized the proposal of a catastrophic flood. The Aksu et al. (2002) "Outflow Hypothesis" differs in several ways from the scenarios presented by Çağatay et al. (2000) and Görür et al. (2001) and was based entirely on our own data and ideas. The similarities to Algan et al. (2001) are more embarrassing for us, but we had not read this paper when we submitted our manuscript to GSA Today. Nevertheless, we apologize to the authors of Çağatay et al. (2000), Görür et al. (2001), and Algan et al. (2001) for unjustifiably ignoring several of their important contributions to the evolution of the Black Sea-Marmara Sea-Aegean Sea oceanographic gateway. Ali E. Aksu and Richard N. Hiscott,

\section{REFERENCES CITED}

\section{Memorial University, Canada}

Aksu, A.E., Hiscott, R.N., Mudie, P.J., Rochon, A., Kaminski, M.A., Abrajano, T., and Yaşar, D., 2002, Persistent Holocene outflow from the Black Sea to the eastern Mediterranean contradicts Noah's Flood Hypothesis: GSA Today, v. 12, no. 5, p. 4-10.

Algan, O., Çağatay, N., Tchepalyga, A., Ongan, D., Eastoe, C., and Gökaşan, E., 2001, Stratigraphy of the sediment infill in Bosphorus Strait: Water exchange between the Black and Mediterranean Seas during the last glacial Holocene: Geo-Marine Letters, v. 20, p. 209-218.

Çağatay, M.N., Görür, N., Algan, O., Eastoe, C., Tchepalyga, A., Ongan, D., Kuhn, T., and Kuşcu, I., 2000, Late Glacial-Holocene palaeoceanography of the Sea of Marmara: Timing of connections with the Mediterranean and the Black Seas: Marine Geology, v. 167, p. 191-206.

Görür, N., Cağatay, M.N., Emre, Ö, Alpar, B., Sakınç, M., Islamoğlu, Y., Algan, O., Erkal, T, Keçer, M., Akkök, R., and Karlık, G., 2001, Is the abrupt drowning of the Black Sea shelf at 7150 yrBP a myth?: Marine Geology, v. 176, p. 65-73. 